\title{
Environmental aspects of the geothermal energy utilisation in Poland
}

\author{
Anna Sowiżdża1 ${ }^{1}$, Barbara Tomaszewska ${ }^{1}$, and Anna Drabik ${ }^{1, *}$ \\ ${ }^{1}$ AGH University of Science and Technology, Faculty of Geology, Geophysics and Environmental \\ Protection, al. A. Mickiewicza 30, 30-059 Kraków, Poland
}

\begin{abstract}
Geothermal energy is considered as a strategic and sustainable source of renewable energy that can be effectively managed in several economic sectors. In Poland, despite the abundant potential of such resources, its share in the energy mix of renewable energy sources remains insubstantial. The utilisation of geothermal resources in Poland is related to the hydrogeothermal resources, however, numerous researches related to petrogeothermal energy resources are being performed. The utilisation of each type of energy, including geothermal, has an impact on the natural environment. In case of the effective development of geothermal energy resources, many environmental benefits are pointed out. The primary one is the extraction of clean, green energy that is characterised by the zeroemission rate of pollutants into the atmosphere, what considering the current environmental pollution in many Polish cities remains the extremely important issue. On the other hand, the utilisation of geothermal energy might influence the natural environment negatively. Beginning from the phase of drilling, which strongly interferes with the local landscape or acoustic climate, to the stage of energy exploitation. It should be noted that the efficient and sustainable use of geothermal energy resources is closely linked with the current law regulations at national and European level.
\end{abstract}

\section{Introduction}

The utilisation of geothermal energy resources, besides many other positive aspects, carries a number of environmental benefits. Currently, this constitutes the particularly important issue due to the constantly increasing problem of a global pollution in numerous regions of Poland, that is mainly related to the use of fossil fuels. The geothermal energy is environment-friendly and its utilisation does not entail the emission of pollutants [1].

The subject area referring to the environmental impact of geothermal energy utilisation has been discussed so far by many Polish and foreign authors. Predominantly, the positive impact on the environment was highlighted [2-4], nevertheless, the potential risks that might occur during the exploitation of geothermal resources were presented [5-8]. Also, the subject of broadly understood legal frameworks that determine the process of the exploitation of geothermal energy resources was introduced [9, 10]. Environmental perils

* Corresponding author: anna7drabik@gmail.com 
may be related to the process of the exploration of geothermal waters (the stage of drilling an exploitive hole) as well as the phase of its exploitation. The paper analyses crucial environmental aspects connected with extraction and utilisation of geothermal energy resources in Polish formal and legal regulations.

\section{Geothermal energy in Poland}

Geothermal energy is distributed unequally around the world. Especially favourable conditions for the formation of geothermal systems containing vapour deposits - potentially best suited for the industrial application - exist within the edge of lithosphere plates: in the rift and subduction zones. In these areas, the most prospective high-temperature geothermal regions are located. Poland is placed outside the aforementioned zones, and the use of geothermal energy is associated with the occurrence of low-temperature geothermal resources $[1,11]$.

In our country, there are natural sedimentary-structural pools filled with geothermal waters that temperatures vary from $20^{\circ} \mathrm{C}$ to even $90^{\circ} \mathrm{C}$, and in the extreme case exceed $100^{\circ} \mathrm{C}$. Geothermal energy resources in Poland are related to the underground waters of different stratigraphic layers occurring at different depths, within geological units in the Polish Lowland, the Sudetes and the Carpathians. The information about their size is widely known thorough results of numerous research projects [12-19]. The recognition of geological structures for direct or indirect applications of the geothermal energy is an important direction of carried geological research. The most prospective regions for geothermal energy development in Poland are connected with Polish Lowlands and Podhale area (Western Carpathians). The principal resources of geothermal waters in the Polish Lowlands are accumulated in the Mesozoic groundwater horizons. Geothermal waters are accumulated first of all in the Lower Jurassic and Lower Cretaceous formations but significant resources of geothermal energy are assembled also in the Upper Jurassic, Middle Jurassic, Upper Triassic and Lower Triassic formations [13].

Since Poland is endowed with low-temperature geothermal resources, primary applications involve the space heating, bathing and recreation as well as balneotherapy. In 2015, six geothermal district heating plants were operating: in Podhale region and municipalities of Pyrzyce, Mszczonów, Poddębice, Uniejów and Stargard Szczeciński. Moreover, 13 recreation centres are located within the country, where geothermal water is used both for swimming pools and other facilities as well as for preparation of hot domestic water. Geothermal water is also utilised in 10 health resorts for healing and rehabilitation purposes. It is worth noting that numerous projects concerning various geothermal aspects have been under development [20,21].

\section{Law regulations}

The text of the internal law in the context of geothermal energy utilisation, has been determined by the conditioning derived from the European Union. Such regulations allow the natural environment to be preserved against the possible negative impact of the geothermal installation.

The notion of geothermal waters is a term commonly used in Polish and world literature. Nevertheless, the Polish law introduces the term of "thermal water", defining it as groundwater that temperature at the outflow of the water intake is not less than $20^{\circ} \mathrm{C}[22$ (Art. 5)]. The most important legal act regulating principles of the exploration, recognition and exploitation of geothermal waters remains the Geological and Mining Law [22]. Under the terms of Art. 5 and Art. 10 of the present act, the geothermal waters are treated as 
minerals and the mining property right is appertained to the State Treasury. Simultaneously, the act constitutes that any mining activities require to obtain the concession, which according to Art. 21.1 [22], is conceded by the proper province marshal. In case of the exploration and recognition of "thermal waters", the obtainment of concession is unrequired, however, the development of a geological project as well as its submission to the aforementioned administration authority are obligatory.

Analysing the process of the acquiring a concession for the exploitation of geothermal waters, the first phase is to develop the project of geological works. The requirements to be met by such a document are prescribed by the relevant Regulation of the Minister of Environment [23]. At this stage, it may be necessary to determine the possible environmental impact of the projected enterprise. As specified in the Regulation of the Council of Ministers [24], drillings with depths exceeding 1,000 $\mathrm{m}$ can have a significant effect on the natural environment, therefore it may be required to obtain a decision on the environmental conditions of the project. In such a case, the entrepreneur is obliged to submit to the competent authorities the information card and/or Environmental Impact Report, which specifies the potential impact of investment on the surface and groundwater quality, emission of pollutant into the atmosphere, waste management, water and sewerage management, landscape, noise emissions and electromagnetic fields. At the phase of geological works aimed at the exploration and recognition of geothermal water resources, the regulations delineated in the section VI, chapter 2 of the Geological and Mining Law [22], concerning the operation of mining works are applied. The results of the conducted geological work including the amount of the exploitable geothermal waters resources should be presented in the hydrogeological documentation prepared in the accordance with guidelines stated by the Art. 88 of the Geological and Mining Law [22] as well as by the Regulation of the Minister of Environment on hydrogeological documentation [25]. The hydrogeological documentation of the reservoir of "thermal water" is a strategic document that constitutes the basis for obtaining the consent for the quantity of extracted water and the method of exploitation. In the case of a positive recognition of hydrogeothermal resources, the document has to specify the conditions of spent water re-injection into the rock, with the indication of methods to be applied for the particular water intake to prevent it against colmatation.

The stage of the acquiring a concession for the mining of "thermal waters" is regulated by the section II, chapter 1 of the Geological and Mining Law [22]. While considering the environmental aspect, the application for a such concession, besides the environmental protection requirements [26], includes also a description of how to eliminate or to constrain the negative impact of a potential activity on the natural environment. In addition, it defines several important issues, like information - on the amounts of geothermal resources and planned extraction, geological and hydrogeological conditions of water extraction, as well as for spent water re-injection back into the rock formation. It should be emphasised that the obtained concession is an important document on the sustainable exploitation of the deposit, moreover it remains the basic act determining the treatment of used geothermal waters. What is substantial, according to the Regulation of the Minister of Environment [27], it is required to prepare a technical documentation (for each injection well separately), which is of the responsibility of the mining plant executive. Other procedures must comply with regulations of the Water Law [28]. According to the Art. 9 of the aforementioned act [28], the spent geothermal water, that is discharged into waters or to the ground is considered as wastewater, and its quality have to meet the requirements included in documents pertaining to the protection of natural environment [29-31]. 


\section{Impact on the environment}

Taking into account the legal regulations referring to the sequentially phases of the exploration, recognition and exploitation of geothermal energy resources, it can be noted that environmental care is important during the each stage, and any potential risks are eliminated at the beginning of investment planning. The evaluation of the operating geothermal installation impact on the natural environment can be made dependable on the perspective - on a global or local scale. Namely, considering the aspect of a reduction on the emission of harmful substances into the atmosphere and thus the diminution of fossil fuels utilisation on a global scale, or in the context of the impact of the particular geothermal installation on the local water and land environment. The extraction of geothermal energy may cause an influence on the state of natural environment, therefore potential hazards should be identified and subsequently eliminated or limited in the accordance with the national legislation.

\subsection{Impact on the air quality}

Due to the use of geothermal energy for space heating purposes in Poland, there is a noticeable improvement of the atmospheric air quality. This is confirmed by the significant ecological effects attained by geothermal installations that started to operate in the $90 \mathrm{~s}$ of the last century. Also, at the present time when the problem of low-emission is increasing constantly and on the other hand, the preservation of natural environment has a crucial role, the possibility of geothermal energy utilisation remains a particularly important issue. The limitation of emissions of gases such as carbon dioxide $\left(\mathrm{CO}_{2}\right)$, carbon monoxide $(\mathrm{CO})$, sulphur dioxide $\left(\mathrm{SO}_{2}\right)$, and particulate matter (PM10) connected with the incineration of fossil fuels, is of particular importance in Podhale region, which is one of the most frequently visited tourist regions in Poland. According to the Geothermal District Heating Plant - Geotermia Podhalańska [32], the average annual concentration of $\mathrm{SO}_{2}$ before the implementation of the geothermal project (1994-1998) equalled to $32,6 \mu \mathrm{g} / \mathrm{m}^{3}$. Currently, as the result of growing number of geothermal heat recipients, the concentration of $\mathrm{SO}_{2}$ amounts to $8-13 \mu \mathrm{g} / \mathrm{m}^{3}$ [32].The matter of PM10 reduction is resembling, the values were $54,3 \mu \mathrm{g} / \mathrm{m}^{3}$ and $43,1 \mu \mathrm{g} / \mathrm{m}^{3}$ before and after the implementation of the geothermal project, respectively [32]. The annual decline of $\mathrm{CO}_{2}$ emission in 2013 totalled $37,35 \times 10^{6} \mathrm{~kg}$ [32]. The reduction of $\mathrm{CO}_{2}$ emissions associated with the development of geothermal district heating in Podhale region in presented on the Fig. 1. 


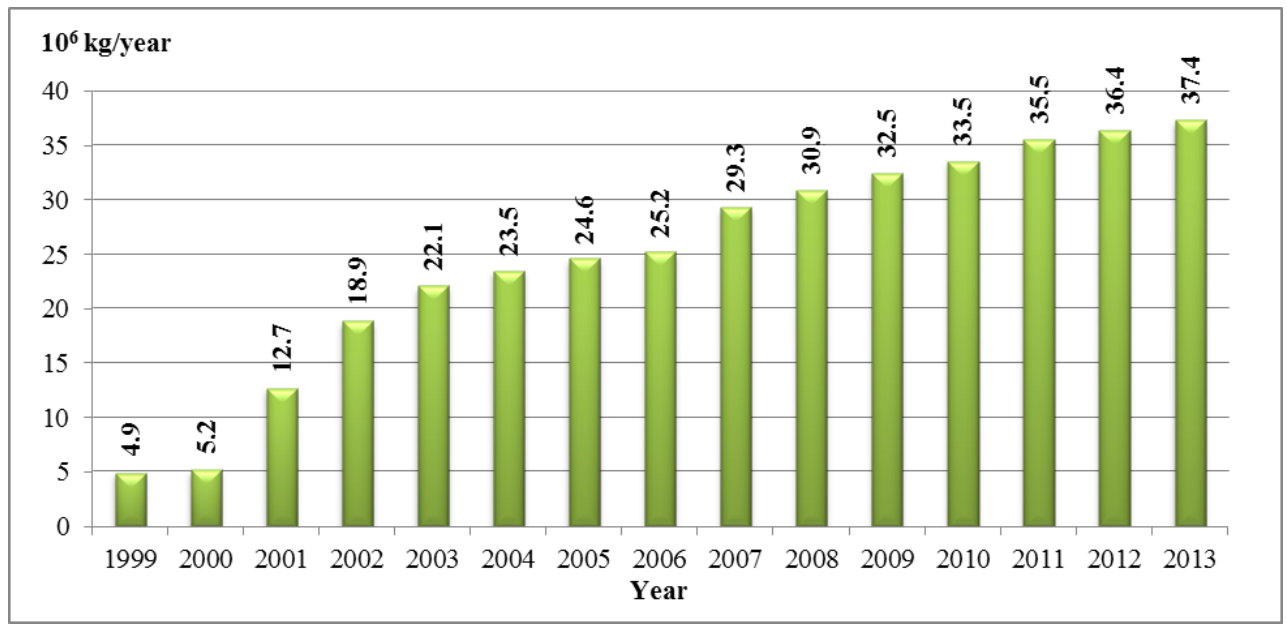

Fig. 1. Reduction of $\mathrm{CO}_{2}$ emissions in years 1999-2013; based on [32]

Also, the remaining geothermal district heating plants have achieved significant ecological effects, contributing to the improvement of a local air quality. The amount of avoided emission into the atmosphere in 2014, depending on the geothermal plant and type of pollutants, is presented in the Table 1.

Table 1. Delimited emission of pollutants in tonnes/year; based on [33-36]

\begin{tabular}{|c|c|c|c|c|c|}
\cline { 2 - 6 } \multicolumn{1}{c|}{} & $\mathrm{SO}_{2}$ & $\mathrm{NO}_{\mathrm{x}}$ & $\mathrm{CO}$ & $\mathrm{CO}_{2}$ & dust \\
\hline $\begin{array}{c}\text { Geothermal } \\
\text { DH Plant } \\
\text { Mszczonów }\end{array}$ & 60 & 14 & no data & 7,278 & 145 \\
\hline $\begin{array}{c}\text { Geothermal } \\
\text { DH Plant } \\
\text { Uniejów }\end{array}$ & 5,320 & 38.06 & 2.5 & 299.05 & 134.72 \\
\hline $\begin{array}{c}\text { Geothermal } \\
\text { DH Plant } \\
\text { Pyrzyce }\end{array}$ & 1,158 & 257.32 & $2,759.68$ & $83,608.8$ & 240.99 \\
\hline $\begin{array}{c}\text { Geothermal } \\
\text { DH Plant } \\
\text { Poddębice }\end{array}$ & 6.2 & 4.4 & 54.7 & 4.3 & 6.3 \\
\hline
\end{tabular}

\subsection{Impact on the water and ground environments}

The most significant impact on the water and ground environments takes place during the drilling phase (mainly as results of a failure) and exploitation of the geothermal waters (the effect of technological errors). At both stages, the possibility of a contamination of groundwater, rendering them to be unsuitable for use, is considered possible to occur. As a result of conducting the unsustainable exploitation of geothermal water deposits, the fluid can be reduced or even completely exhausted in the definite reservoir. At the same time, the inherent peril associated with the issue of over-exploitation of geothermal water deposits is the problem of possible land deformations (e.g. subsidence, horizontal displacement of rock masses, etc.). Also, as the result of the exploitation of geothermal waters, the rock formation can be cooled down. What is more, the potential risk may be the so-called cold front breakthrough, i.e. the temperature of the reservoir come down as the effect of reinjection of waste waters at much lower temperature (the effect of an incorrectly designed 
installation). Considering the subject of injecting or discharging spent water into surface water, it is impossible to ignore the potential risk of influence on the mineralisation, $\mathrm{pH}$ and temperature of formation waters.

The re-injection of used (cooled down) geothermal waters into the rock formation is the best and the most optimal solution for its disposal. This aspect is particularly required in cases of the extraction of saline waters (usually with mineralisation above $3 \mathrm{~g} / \mathrm{L}$ ). On practical side, the boundary mineralisation of the geothermal water that requires the implementation of injection wells is determined by the proper Regulation of the Minister of Environment [30]. Only the fulfilment of terms contained in the aforementioned regulation, provides an opportunity to obtain the water-legal permit for discharging waste waters into the surface water. Besides the total dissolved solids (TDS), chloride and sulphur content, geothermal waters may contain elevated concentrations of heavy metals and toxic microelements such as chromium, arsenic and boron. Also, the temperature of discharged waters has an significant importance - too high can cause damages to the environment of inland fisheries [31], which is often a factor precluding the entrepreneur from acquiring the permission for dropping waste water into the river.

\subsection{Impact on the landscape and acoustic climate}

Impact on the local landscape should be considered in the context of the temporary and long-term changes. The short-term impact on the local landscape is principally relevant to the drilling phase - the appearance of drilling rigs, equipment and machinery necessary for running work, as well as the infrastructure for the staff. However, this element is of short duration, usually does not exceed half a year. As for long-term changes, an interference in the landscape is slightly larger. The magnitude of changes in the local landscape largely depends on the current status and use of the area, i.e. mainly whether there is a need for drastic changes in the land use (e.g. deforestation) or the necessity to build transport infrastructure, etc. However, in contrast to exploratory drilling for fossil fuels purposes (gas, petroleum), geothermal wells geared towards obtaining heat energy, are usually located in the close vicinity of recipients - in areas of existing settlements, often with the high-density housing. This is an important factor associated with the limitation of energy losses on the way from the water intake, through the geothermal heat plant to the heat and hot water users.

Another important issue of the analysis proceeded at the exploratory stage is the impact of drilling works on the acoustic climate. Deep hole drilling requires active and uninterrupted 24-hours work. Drilling facilities like compressors, power generators, pumping equipment and, above all, drilling rigs always generate noise that can be disruptive to the local environment. The impact range of the drilling rig in terms of acoustic impact as well as vibration and electromagnetic fields constitutes the important part of the detailed Environmental Impact Assessment.

\section{Environmental impacts of Enhanced Geothermal Systems (EGS)}

The petrogeothermal energy accumulated within hot dry (or hardly dry) rocks, is exploited on the surface by Enhanced Geothermal Systems (EGS). An Enhanced Geothermal System is an underground reservoir that has been created or improved artificially. Such systems are not currently used in Poland, thus there is no Polish experience in the environmental impact of EGS installation. Nevertheless, environmental aspects concerning the functioning of this type of installation are known worldwide. Most of them are not significantly different from 
the conventional geothermal installation. However, there are several disparate environmental aspects related only to the EGS installation, that should be identify in order to mitigate their negative impact on the natural environment and make the most of this ecological source of geothermal energy.

Most of potentially important environmental impacts of EGS are associated with ground water use and contamination, and with related concerns about land subsidence and induced seismicity as a result of water injection and production into and out of a fractured reservoir formation. Issues of noise, safety, visual impacts and land use associated with drilling and production operations are also important but fully manageable [37]. To create an EGS, stimulation techniques are needed. The stimulation of EGS is to increase the permeability and to create a loop. Moderated quantity of water is used and it is re-injected in any case so the EGS do not produce wastewater by products [38].

Stimulation techniques may cause induced seismicity that may be sufficiently intense to be felt on the surface. Although induced seismicity can be used as a monitoring tool to understand the effectiveness of EGS operations and shed light on the mechanics of the reservoir, there is some risk that, particularly in seismically quiet areas, operation of an EGS reservoir under pressure for sustained periods may trigger a felt earthquake [37]. EGS projects require access to water during several stages of development and operation. In most advanced EGS applications, surface water will be needed to both stimulate and operate the reservoir and produce the needed circulation patterns. The water may be taken from a nearby high flow stream or river, if available, or collected in a temporary surface reservoir during the rainy season, thusly EGS systems may be approximated as "closed-loop". However, the circulation system is not exactly closed because water is lost to the formation; this lost water must be made up from surface water supplies [37].

The present issue does not concern Polish geothermal installations, which use hydrogeothermal energy, however, together with the growth of geothermal energy sector, the development of EGS technology is expected. Then, the knowledge of these specific and possible impacts on the natural environment will be crucial.

\section{Conclusion}

Geothermal energy is considered ecological and renewable source of energy that can become an alternative for the Polish energy sector founded on fossil fuels, mainly for the purposes of space heating and hot water supply. The compliance with the formal and legal regulations together with applying the good practice during the various phases of exploration, recognition and extraction of geothermal resources significantly reduces the negative impact on the natural environment of the considered geothermal investments. However, at this stage, it is impossible to omit the issue of the positive impact on the environment of the use of geothermal energy. The avoided emissions of pollutants into the atmosphere $\left(\mathrm{SO}_{2}, \mathrm{NO}_{\mathrm{x}}, \mathrm{CO}, \mathrm{CO}_{2}\right.$, dust) in all geothermal areas in Poland are not only numbers, but also better living conditions and, above all, the possibility to breathe clean air.

The paper has been prepared under the AGH-UST statutory research grant No. 11.11.140.321.

\section{References}

[1] B. Tomaszewska, A. Szczepański, Renew. Energ. 21: 11409-1147 (2014)

[2] R. Shortall, B. Davidsdóttir, G. Axelsson, Renew. Sust. Energ. Rev. 44: 391-406 (2015)

[3] B. Towler, The Future of Energ.: 237-256 (2014) 
[4] A. de Jesus, Geotherm. Power Gener.: 477-498 (2016)

[5] R. DiPippo, Geotherm. Power Pl.: 657-684 (2016)

[6] E. Garrido Schneider, A. Garcia-Gil, E. Vázquez-Suñè, J. Sánchez-Navarro, Sci. Total. Environ. 544: 354-368 (2016)

[7] R. Allis, C. Bromley, S. Currie, Geothermics 38, 1: 169-180 (2009)

[8] K. Brown, Sci. Total. Environ. 22, 1: 61-77 (1981)

[9] E.R. Arias, Geotherm. Pow. Gen.: 763-786 (2016)

[10] S. Haehnlein, P. Bayer, P. Blum, Renew. Sust. Energ. Rev. 14, 9: 2611-2625 (2010)

[11] A. Drabik, A Sowiżdżał, Geology, Geophysics\&Environ. 4 (2017)

[12] W. Bujakowski, B. Tomaszewska, M. Miecznik, Renew. Energ. 99: 420-430 (2016)

[13] W. Górecki, A. Sowiżdżał, M. Hajto, A. Wachowicz-Pyzik, Environ. Earth Sci. 74: 7487-7495 (2015)

[14] M. Miecznik, A. Sowiżdżał, B. Tomaszewska, L. Pająk, Geologos 21, 3 (2015)

[15] A. Sowiżdżał, Carpath. J. Earth Env. 10: 237-246 (2015)

[16] A. Sowiżdżał, M. Kaczmarczyk, Geol. J. 51: 65-76 (2016)

[17] A. Sowiżdżał, Appl. Ecol.Environ. Res. 14, 2: 555-574 (2016)

[18] W. Bujakowski, A. Barbacki, M. Miecznik, L. Pająk, Renew. Energ. 80 (2015)

[19] A. Sowiżdżał, B. Papiernik, G. Machowski, M. Hajto, Geol. Quart. 57: 729-744 (2013)

[20] B. Kępińska, Geothermal Energy Use - Country Update for Poland, 2013-2015, (EGC Proceedings, Strasbourg, France, 2016)

[21] B. Kępińska, Geothermal Energy Country Update Report from Poland, 2010-2014, (WGC Proceedings, Melbourne, Australia, 2015)

[22] Ustawa Prawo Geologiczne i Górnicze (Dz. U. 2016 poz. 1131)

[23] Rozporządzenie Ministra Środowiska w sprawie szczegółowych wymagań dotyczących projektów robót geologicznych, w tym robót, których wykonywanie wymaga pozyskania koncesji (Dz. U. $2011 \mathrm{nr} 288$ poz. 1696)

[24] Rozporządzenie Rady Ministrów w sprawie przedsięwzięć mogących znacząco oddziaływać na środowisko (Dz. U. 2016 poz. 71)

[25] Rozporządzenie Ministra Środowiska w sprawie dokumentacji hydrogeologicznej i dokumentacji geologiczno-inżynierskiej (Dz. U. 2016 poz. 2033)

[26] Ustawa o udostępnianiu informacji o środowisku i jego ochronie, udziale społeczeństwa w ochronie środowiska oraz o ocenach oddziaływania na środowisko (Dz.U. 2016poz. 353)

[27] Rozporządzeniem Ministra Gospodarki w sprawie szczegółowych wymagań dotyczących prowadzenia ruchu zakładów górniczych wydobywających kopaliny otworami wiertniczymi, zatłaczanie wody do górotworu (Dz. U. 2014 poz. 812)

[28] Ustawa Prawo Wodne (Dz. U. 2015 poz. 469)

[29] Ustawa Prawo ochrony środowiska (Dz. U. 2017 poz. 519)

[30] Rozporządzenie Ministra Środowiska w sprawie warunków jakie należy spełniać przy wprowadzaniu ścieków do wód lub do ziemi, oraz w sprawie substancji szczególnie szkodliwych dla środowiska wodnego (Dz. U. 2014 poz. 1800)

[31] Rozporządzenie Ministra Środowiska w sprawie wymagań jakim powinny podlegać wody śródlądowe będące środowiskiem życia ryb w warunkach naturalnych (Dz. U. 2002 Nr 176 poz. 1455) 
[32] PEC Geotermia Podhalańska, (11/03/2017: http://geotermia.pl/ochrona-srodowiska/)

[33] ZG Mszczonów (11/03/2017: http://mineralne.pgi.gov.pl/geotermia.html?id=2405)

[34] Geotermia Uniejów (11/03/2017: http://www.pnec.org.pl/smart/pdf/uniejow.pdf)

[35] Geotermia Pyrzyce (11/03/2017: http://geotermia.inet.pl/ochrona_srodowiska.php)

[36] Geotermia Poddębice (11/03/2017:

http://www.chronmyklimat.pl/projekty/klimapolka/wiadomosci/geotermia-ogrzewapoddebice)

[37] J.W. Tester, B.J. Anderson, A.S. Batchelor, D.D. Blackwell, R. Dipippo, E.M. Drake, J. Garnish, B. Livesay, M.C. Moore, K. Nichols, S. Petty, M.N. Toksoz, R.W. Veatch, The Future of Geothermal Energy. Impact of Enhanced Geothermal Systems (EGS) on the United States in the 21st Century (Massachusetts Institute of Technology, 2006)

[38] Geoelec, Environmental study on geothermal power. Geoelec report (2013) 